\title{
TRITIUM ANALYSES OF SHALLOW GROUND WATER IN MISSISSIPPI, APRIL 1989
}

By Larry J. Slack and William T. Oakley

U.S. GEOLOGICAL SURVEY

Open-File Report 89-418

Prepared in cooperation with the

MISSISSIPPI DEPARTMENT OF ENVIRONMENTAL QUALITY, BUREAU OF POLLUTION CONTROL

Jackson, Mississippi

1989 


\section{DEPARTMENT OF THE INTERIOR \\ MANUEL LUJAN, JR., Secretary \\ GEOLOGICAL SURVEY \\ Dallas L. Peck, Director}

For additional information write to:

\section{District Chief}

U.S. Geological Survey

Suite 710, Federal Building

100 W. Capitol Street

Jackson, Mississippi 39269
Copies of this report can be purchased from:

U.S. Geological Survey

Books and Open-File Reports

Building 810

Box 25425, Federal Center

Denver, Colorado 80225 


\section{CONTENTS}

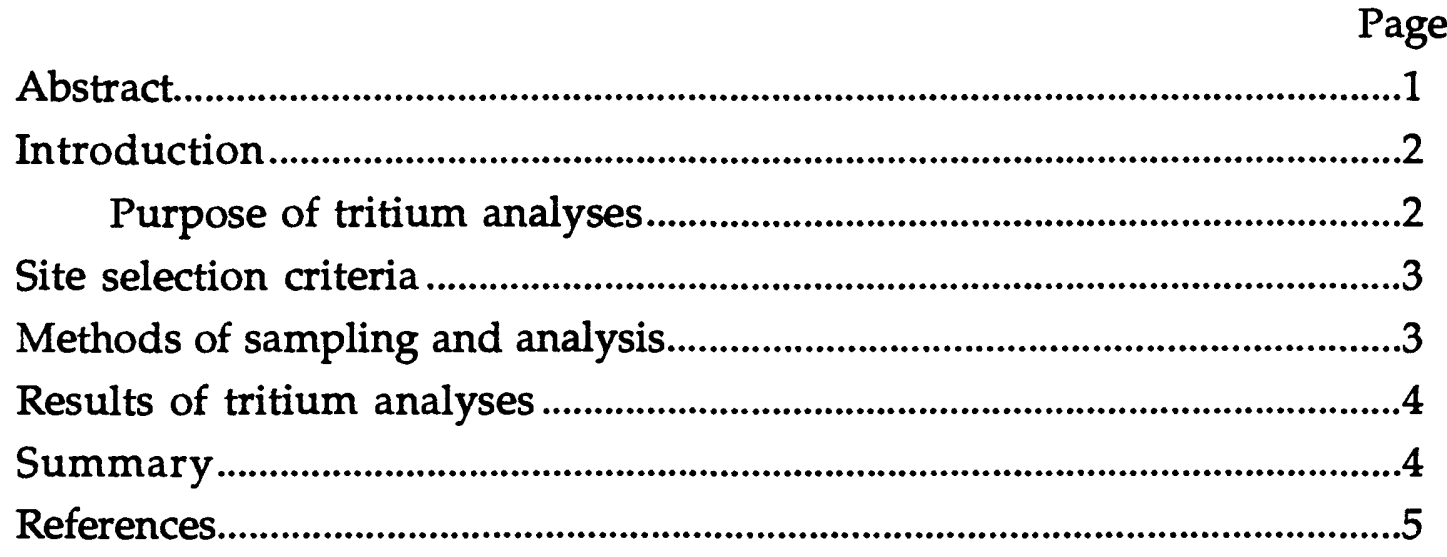

\section{ILLUSTRATIONS}

Figure 1. Map showing location of ground-water sites for tritium analyses

.6

\section{TABLES}

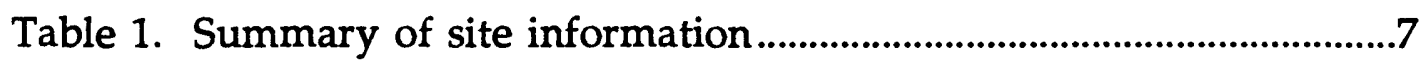

2. Values for tritium and selected water-quality properties and constituents for ground water at selected sites in Mississippi..8 


\section{CONVERSION FACTORS}

For readers who may prefer to use the metric (International System) of units rather than the inch-pound units used herein, the conversion factors are listed below:

Multiply inch-pound unit

foot $(f t)$

gallon per minute ( $\mathrm{gal} / \mathrm{min})$

degree Fahrenheit $\left({ }^{\circ} \mathrm{F}\right)$ by

25.4

0.06308

${ }^{\circ} \mathrm{C}=5 / 9 \times\left({ }^{\circ} \mathrm{F}-32\right)$
To obtain metric unit

millimeter (mm)

liter per second $(\mathrm{L} / \mathrm{s})$

degree Celsius $\left({ }^{\circ} \mathrm{C}\right)$

\section{ABBREVIATIONS}

$\begin{array}{ll}\mathrm{mg} / \mathrm{L} & \text { milligram per liter } \\ \mathrm{pCi} / \mathrm{L} & \text { picocurie per liter } \\ \mathrm{TU} & \text { tritium unit } \\ \mu \mathrm{S} / \mathrm{cm} & \text { microsiemens per centimeter at } 25^{\circ} \mathrm{C}\end{array}$ 


\title{
TRITIUM ANALYSES OF SHALLOW GROUND WATER IN MISSISSIPPI, APRIL 1989
}

by Larry J. Slack and William T. Oakley

\begin{abstract}
In April 1989, the U.S. Geological Survey collected water samples from 22 shallow wells (less than 400 feet deep) for tritium analyses; the wells are completed in 11 of the principal aquifers in Mississippi. Tritium concentrations ranged from less than 0.3 to 42 picocuries per liter. Tritium concentrations in water from 50 percent of the wells were greater than 1 picocurie per liter, indicating modern (post-1953) water.
\end{abstract}




\section{INTRODUCTION}

This study is part of the Federal-State Cooperative Program, conducted by the U.S. Geological Survey and State and local agencies. The principal program objectives are: (1) to collect, on a systematic basis, data needed for the continuing determination and evaluation of the quantity, quality, and use of water resources in the United States, and (2) to appraise the availability of ground and surface water through analytical and interpretive investigations. The resulting information forms the foundation for many of the Nation's water-resources management and planning activities and allows for the detection of emerging water problems.

The principal State agencies in Mississippi responsible for ground-water management and protection are the Bureau of Pollution Control (BPC), the Bureau of Land and Water Resources, and the Bureau of Geology of the Mississippi Department of Environmental Quality.

The Groundwater Planning Section, Groundwater Protection Division of the BPC, is responsible for the development of ground-water protection programs. The long-term objective of those programs is both to develop and to administer the regulatory activities necessary to protect the State's groundwater resources; short-term objectives include investigating ground-water recharge rates for selected aquifers in the State associated with the Well Head Evaluation Program (C. Smith, Mississippi Bureau of Pollution Control, written commun., July, 1989). This study was made to help meet the objectives of the USGS and the BPC.

\section{Purpose of Tritium Analyses}

Tritium has been used extensively as a hydrologic tracer since the early 1950's and can be used to indicate the relative age of water. Tritium is particularly useful in ground-water studies because it is relatively unaffected by reactions other than radioactive decay.

Tritium is a radioactive isotope of hydrogen with an atomic weight of 3 and a half-life of 12.43 years. Tritium is produced naturally, in a small but 
near steady-state concentration (Michel, 1989, p.3), in the atmosphere. Prior to the initiation of atmospheric testing of large thermonuclear weapons in 1953, the natural tritium content of rainwater was about 1 to 5 tritium atoms per $10^{18}$ normal hydrogen atoms (Thatcher, 1962, p. 48), or 1 to 5 tritium units (TU). In the 1950's and 1960's, tritium concentrations in precipitation in the northern hemisphere increased 2 or 3 orders of magnitude--to about 50 TU for surface ocean water and 100's or 1000's of TU for some continental water.

\section{SITE SELECTION CRITERIA}

In April 1989, the U.S. Geological Survey collected water samples from 22 shallow wells (less than 400 feet deep) (fig. 1) for tritium analyses; the wells are completed in 11 of the principal aquifers in Mississippi. It is essential that complete and accurate well-construction information be available for each site; consequently, first preference was given to public-supply wells for which geophysical logs are available. Wells were selected that were in use, had turbine or submersible pumps, and had a yield of at least 50 gallons per minute (table 1).

\section{METHODS OF SAMPLING AND ANALYSIS}

To assure that samples were representative of water from the waterbearing unit, the wells were pumped long enough prior to sampling to evacuate at least twice the volume of water in the casing. Most of the wells sampled were in daily operation, and some were in continuous operation.

Water samples for tritium analysis were collected in a narrow-mouth flint glass bottle with a polyseal cap. Water was pumped into the bottle until it reached near the top, with care taken not to entrain air. The bottle was capped, and the cap was taped to prevent it from loosening during transit.

The samples were shipped to the Water Resources Division National Water Quality Laboratory (NWQL) in Denver, Colorado, where they were recorded, repackaged, and forwarded to the University of Miami Tritium Laboratory. The samples were analyzed by an electrolytic enrichment with gas counting method developed by Ostlund and Werner (1961). It is the most sensitive method available through the NWQL. The lower detection limit is 0.3 picocurie per liter. [One $T U=3.2$ picocuries per liter of water.] 


\section{RESULTS OF TRITIUM ANALYSES}

Tritium concentrations for the 22 wells (table 2) are in picocuries per liter; for the convenience of the reader, tritium units (which were obtained by dividing picocuries per liter by a conversion factor of 3.2) are also shown. Temperature, specific conductance, $\mathrm{pH}$, and alkalinity data for water from the 22 wells are also included in table 2.

Tritium concentrations less than about 1 picocurie per liter are considered to represent water with natural or background levels of tritium for ground water in Mississippi (R.L. Michel, USGS, oral commun., September 13, 1989). Values greater than 1 picocurie per liter are considered to represent post-1953 water, which is commonly referred to as "modern water" or "bomb tritium water." The limited amount of tritium data obtained during this study precludes drawing conclusions about the typical concentrations for any given aquifer.

Tritium concentrations ranged from less than 0.3 (the lower detection limit) to 42 picocuries per liter. Tritium concentrations in water from 10 of the wells were less than the lower detection limit. In 50 percent of the wells, tritium concentrations were greater than 1 picocurie per liter, indicating modern (post-1953) water.

\section{SUMMARY}

In April 1989, the U.S. Geological Survey collected water samples from 22 shallow wells (less than 400 feet deep) for tritium analyses; the wells are completed in 11 of the principal aquifers in Mississippi. Tritium concentrations ranged from less than 0.3 to 42 picocuries per liter. Tritium concentrations in water from 50 percent of the wells were greater than 1 picocurie per liter, indicating modern (post-1953) water. 


\section{REFERENCES}

Michel, R.L., 1989, Tritium deposition in the continental United States, 1953-83: U.S. Geological Survey Water-Resources Investigations Report 89-4072, 51 p.

Ostlund, H.G., and Werner, E., 1961, The electrolytic enrichment of tritium and deuterium for natural tritium measurements: Tritium in the Physical and Biological Sciences, Proceedings, vol. 1, p. 95-105.

Thatcher, L.L., 1962, The distribution of tritium fallout in precipitation over North America: International Association of Science Hydrology Bulletin, vol. 7, no. 2, p. 48. 


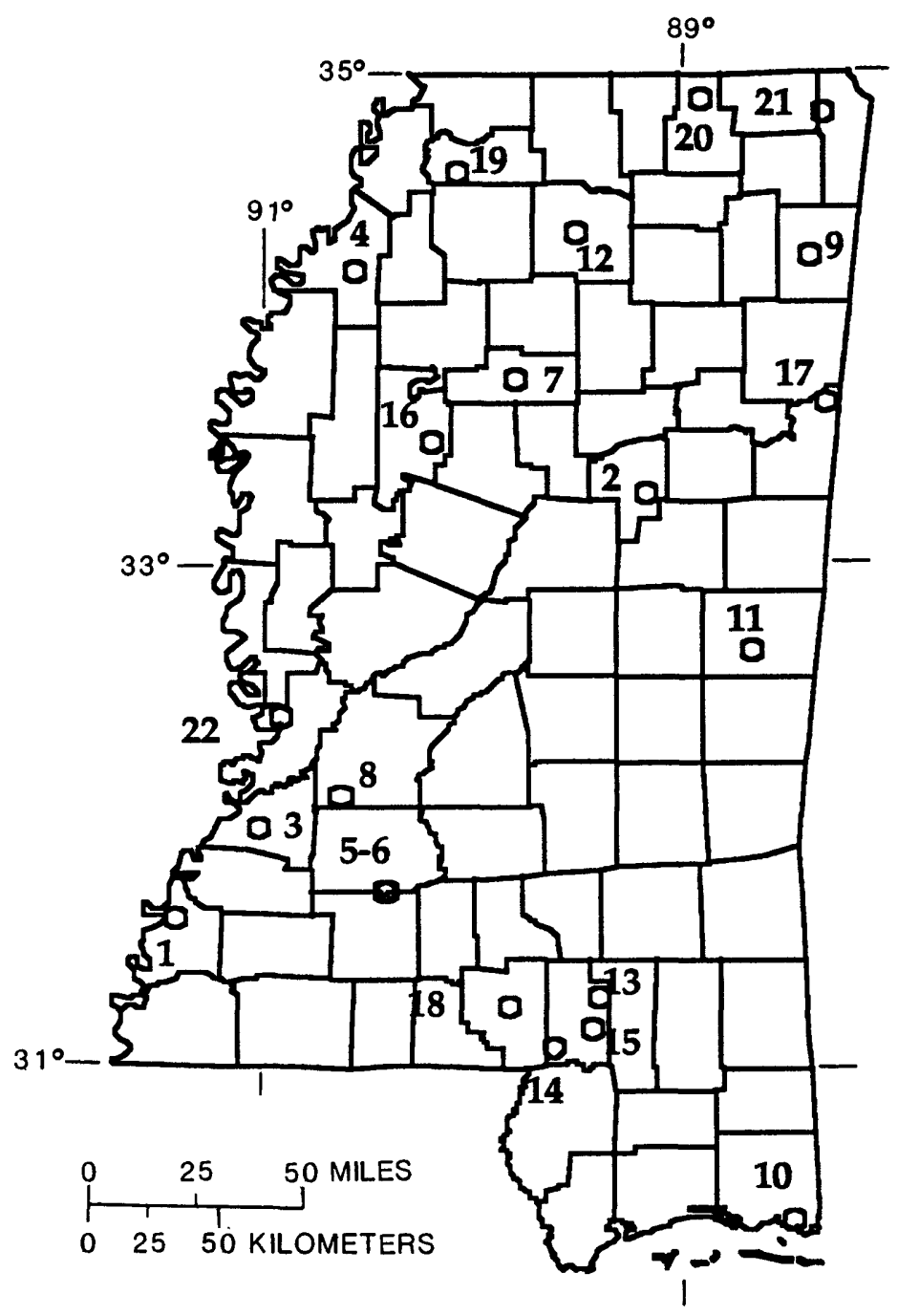

Figure 1.--Location of ground-water sites for tritium analyses. 
Table 1. Summary of site information

[ft, feet; gal/min, gallons per minute; Util, Utilities; W A, Water Association]

\begin{tabular}{|c|c|c|c|c|c|c|}
\hline $\begin{array}{l}\text { Site } \\
\text { no. } \\
\text { (see } \\
\text { fig.1) }\end{array}$ & County & $\begin{array}{l}\text { Local well number } \\
\text { and name of owner } \\
\text { or city }\end{array}$ & $\begin{array}{c}\text { Depth } \\
\text { of well } \\
(f t)\end{array}$ & $\begin{array}{c}\text { Top, } \\
\text { open } \\
\text { interval } \\
(\mathrm{ft})(\end{array}$ & $\begin{array}{c}\text { Well } \\
\text { yield } \\
\text { (gal } / \mathrm{min})\end{array}$ & $\begin{array}{l}\text { Aquifer or } \\
\text { aquifer system }\end{array}$ \\
\hline 1 & Adams & D045 Broadmoore Util & 150 & 135 & 250 & Miocene \\
\hline 2 & Choctaw & H030 Ackerman & 101 & 64 & 360 & Middle Wilcox \\
\hline 3 & Claiborne & L079 Port Gibson & 170 & 110 & 140 & Catahoula \\
\hline 4 & Coahoma & J009 Clarksdale & 357 & 307 & 2,000 & Sparta \\
\hline 5 & Copiah & V019 Wesson & 332 & 292 & 340 & Catahoula \\
\hline 6 & Copiah & V025 Wesson & 360 & 320 & 380 & Catahoula \\
\hline 7 & Grenada & H013 Grenada & 170 & 145 & 600 & Meridian-Upper Wilcox \\
\hline 8 & Hinds & S016 Utica & 298 & 258 & 240 & Catahoula \\
\hline 9 & Itawamba & H021 Fulton & 274 & 223 & 350 & Gordo \\
\hline 10 & Jackson & Q420 Pascagoula & 346 & 266 & 600 & Graham Ferry \\
\hline 11 & Kemper & N016 Kipling W A & 178 & 138 & 200 & Lower Wilcox \\
\hline 12 & Lafayette & F023 Oxford & 96 & 71 & 600 & Meridian-Upper Wilcox \\
\hline 13 & Lamar & E209 N Lamar W A & 187 & 147 & 200 & Miocene \\
\hline 14 & Lamar & J276 N Lumberton W A & 202 & 160 & 220 & Miocene \\
\hline 15 & Lamar & L093 Progress W A & 264 & 222 & 200 & Miocene \\
\hline 16 & Leflore & L154 Greenwood & 220 & 160 & 1,900 & Sparta \\
\hline 17 & Lowndes & B030 Caledonia & 323 & 283 & 110 & Gordo \\
\hline 18 & Marion & L002 Columbia & 140 & 110 & 1,200 & Miocene \\
\hline 19 & Tate & F048 Strayhorn W A & 316 & 276 & 220 & Sparta \\
\hline 20 & Tippah & D014 Tipplersville W A & 190 & 130 & 120 & Ripley \\
\hline 21 & Tishomingo & D052 Burnsville & 280 & 230 & 350 & Paleozoic \\
\hline 22 & Warren & E023 Vicksburg & 122 & 82 & 1,000 & Miss. River Valley alluvium \\
\hline
\end{tabular}


Table 2. Values for tritium and selected water-quality properties and constituents for ground water at selected sites in Mississippi

[pCi/L, picocuries per liter; TU, tritium units; ${ }^{\circ} \mathrm{C}$, degrees Celsius; $\mu \mathrm{S} / \mathrm{cm}$, microsiemens per centimeter; $\mathrm{mg} / \mathrm{L}$, milligrams per liter]

\begin{tabular}{|c|c|c|c|c|c|c|c|}
\hline \multirow{2}{*}{$\begin{array}{l}\text { Site no. } \\
\text { (see } \\
\text { fig. 1) }\end{array}$} & \multirow[t]{2}{*}{ Date } & \multicolumn{2}{|c|}{$\begin{array}{c}\text { Tritium } \\
\text { concentration } \\
\end{array}$} & \multirow{2}{*}{$\begin{array}{l}\text { Temper } \\
\text { ature } \\
\left({ }^{\circ} \mathrm{C}\right) \\
\end{array}$} & \multirow{2}{*}{$\begin{array}{c}\text { Specific } \\
\text { conductance } \\
(\mu \mathrm{S} / \mathrm{cm})\end{array}$} & \multirow{2}{*}{$\begin{array}{r}\mathrm{pH} \\
\text { (units) }\end{array}$} & \multirow{2}{*}{$\begin{array}{l}\text { Alkalinity } \\
\text { (mg/L as } \\
\left.\mathrm{CaCO}_{3}\right)\end{array}$} \\
\hline & & $(\mathrm{pCi} / \mathrm{L})$ & (TU) & & & & \\
\hline 1 & $04-20-89$ & 41 & 12.8 & 19.5 & 540 & 6.7 & 288 \\
\hline 2 & $04-18-89$ & 20 & 6.2 & 18.0 & 110 & 5.2 & 8 \\
\hline 3 & $04-20-89$ & 4.3 & 1.3 & 20.0 & 498 & 6.8 & 246 \\
\hline 4 & $04-26-89$ & $<0.3$ & $<0.1$ & 17.0 & 450 & 7.1 & 251 \\
\hline 5 & $04-19-89$ & 34 & 10.6 & 20.0 & 65 & 5.2 & 7 \\
\hline 6 & $04-19-89$ & 38 & 11.8 & 20.0 & 45 & 5.3 & 6 \\
\hline 7 & $04-25-89$ & $<0.3$ & $<0.1$ & 19.0 & 340 & 7.6 & 148 \\
\hline 8 & $04-20-89$ & $<0.3$ & $<0.1$ & 21.0 & 580 & 7.4 & 179 \\
\hline 9 & $04-19-89$ & $<0.3$ & $<0.1$ & 17.0 & 100 & 6.6 & 24 \\
\hline 10 & $04-18-89$ & $<0.3$ & $<0.1$ & 23.0 & 920 & 7.7 & 299 \\
\hline 11 & $04-21-89$ & 31 & 9.7 & 18.5 & 38 & 5.1 & 2 \\
\hline 12 & $04-25-89$ & 42 & 13.1 & 17.0 & 80 & 5.6 & 13 \\
\hline 13 & $04-19-89$ & 14 & 4.4 & 20.5 & 24 & 5.6 & 5 \\
\hline 14 & $04-19-89$ & 31 & 9.7 & 20.5 & 22 & 5.1 & 3 \\
\hline 15 & $04-19-89$ & $<0.3$ & $<0.1$ & 21.0 & 30 & 5.6 & 11 \\
\hline 16 & $04-25-89$ & 0.9 & 0.3 & 19.0 & 420 & 7.2 & 234 \\
\hline 17 & $04-20-89$ & $<0.3$ & $<0.1$ & 18.0 & 110 & 6.4 & 25 \\
\hline 18 & $04-19-89$ & 12 & 3.8 & 21.0 & 46 & 5.6 & 9 \\
\hline 19 & $04-25-89$ & $<0.3$ & $<0.1$ & 18.0 & 80 & 6.5 & 38 \\
\hline 20 & $04-18-89$ & $<0.3$ & $<0.1$ & 17.0 & 380 & 7.4 & 192 \\
\hline 21 & $04-19-89$ & $<0.3$ & $<0.1$ & 16.5 & 100 & 6.6 & 20 \\
\hline 22 & $04-20-89$ & 17 & 5.3 & 18.5 & 525 & 6.7 & 258 \\
\hline
\end{tabular}

